DE

M E D I C I N A

T R O P I C A L

$\mathrm{DE}$

SÃO PAULO

JOURNAL OF THE SÃO PAULO INSTITUTE OF TROPICAL MEDICINE

(1) FIOCRUZ, Instituto Oswaldo Cruz, Laboratório Interdisciplinar de Vigilância Entomológica em Diptera e Hemiptera, Rio de Janeiro, Rio de Janeiro, Brazil

(2) FIOCRUZ, Instituto Oswaldo Cruz, Laboratório de Epidemiologia e Sistemática Molecular, Rio de Janeiro, Rio de Janeiro, Brazil

(3) FIOCRUZ, Escritório Técnico Regional

Piauí, Teresina, Piauí, Brazil

*These authors contributed equally

Correspondence to: Silvia Menezes dos Santos

FIOCRUZ, Instituto Oswaldo Cruz, Laboratório Interdisciplinar de Vigilância Entomológica em Diptera e Hemiptera, Av. Brasil, 4365, Manguinhos, CEP 21040-360, Rio de Janeiro, RJ, Brazil.

E-mail: smenezes5@yahoo.com.br

Received: 17 February 2017

Accepted: 04 April 2017

\section{Entomological survey in the state of Piauí, Northeastern Brazil, reveals intradomiciliary colonization of Triatoma brasiliensis macromelasoma}

\author{
Silvia Menezes dos Santos ${ }^{1,2 *}$, Danielle Misael de Sousa1*, Jessica Pereira \\ dos Santos ${ }^{2,3}$, José Felipe Pinheiro do Nascimento Vieira², Teresa Cristina \\ Monte Gonçalves ${ }^{1}$, Jacenir Reis dos Santos-Mallet ${ }^{1}$, Filipe Anibal Carvalho- \\ Costa $^{2,3}$
}

\section{ABSTRACT}

This survey aimed to assess the presence of triatomine vectors of Chagas disease within the rural communities of São João do Piauí, Northeast Brazil. Intradomiciliary and peridomiciliary collection strategies were implemented wherein 279 specimens of Triatoma brasiliensis macromelasoma, both nymph and adult were found in $15(50 \%)$ of the studied homes. Of the intradomiciliary insects, $73(67.6 \%)$ were identified as nymph instars $\left(1^{\text {st }}\right.$ instar $[\mathrm{N} 1]=6, \mathrm{~N} 2=14, \mathrm{~N} 3=28, \mathrm{~N} 4=7$ and $\mathrm{N} 5=18$ ). In the studied communities, a continuous interaction between triatomine bugs and humans could be shown. It is therefore urgent that suitable strategies for the control of the triatomine vector are implemented in this area.

KEYWORDS: Chagas disease. Triatoma brasiliensis macromelasoma. State of Piauí.

\section{INTRODUCTION}

Chagas disease is caused by the protozoan Trypanosoma cruzi (Chagas, 1909), which persists zoonotically in the environment within several species of mammals and is transmitted by hematophagous insects called triatomines (Hemiptera, Reduviidae, Triatominae) $)^{1,2}$. In the past, control strategies for this disease have been implemented effectively in Brazil, such as the Control Program of Chagas Disease (PCDCh) which was established in 1975 by the extinct agency known as the Superintendency of Public Health Campaigns (SUCAM).

The actions of the program have successful and substantially reduced the incidence of the disease in main endemic areas. In 2006, Brazil was certified by the Pan American Health Organization/ World Health Organization as having succeeded in stopping the transmission of Chagas disease by its main vector, Triatoma infestans (Klug, 1834). T. infestans is an introduced vector and, as such, exhibits virtually no significant stocks in the sylvatic environment, making it vulnerable to targeted reduction, as achieved through PCDCh actions ${ }^{3,4}$ with insecticides.

In Northeast Brazil, native triatomine species such as Triatoma brasiliensis (Neiva, 1911), among others, are the predominant vectors of Chagas disease ${ }^{5-7}$. Triatoma brasiliensis is a complex of seven species: i) T. brasiliensis, comprised of two subspecies [T. b. brasiliensis and T. b. macromelasoma (Galvão, 1956)], ii) T. juazeirensis (Costa \& Felix, 2007, iii) T. sherlocki (Papa, Jurberg, Carcavallo, Cerqueira \& Barata, 2002, iv) T. melanica (Neiva \& Lent, 1941, v) T. lenti (Sherlock 
\& Serafim, 1967, vi) T. bahiensis (Sherlock \& Serafim, 1967, and vii) T. petrocchiae (Pinto \& Barreto, 1925) ${ }^{8,9}$.

These insects, which are capable of re-colonizing the domestic environment from wild stocks, represent an enormous challenge to the control of Chagas disease ${ }^{10}$. Consequently, reduction of entomological surveillance and domestic insecticide spraying practices can lead to the re-colonization of homes by triatomines. This, in turn, increases and protracts the human-triatomine contact, consequently producing new cases of Chagas disease ${ }^{11}$.

The aims of this survey are to assess the presence of triatomine vectors both in and around domestic units of rural communities where vector control is intermittent in the State of Piauí, Northeast Brazil.

\section{MATERIALS AND METHODS}

The study was performed in 11 rural communities in São João do Piauí, Piauí State, Brazil (08²1'29” S/ $42^{\circ} 14^{\prime} 48^{\prime \prime}$ 'W'; altitude $222 \mathrm{~m}$; human development index = 0.65) (see map in Figure 1), in December 2016 (beginning of rainy season). This municipality has 22,452 inhabitants dispersed over $1,532,432 \mathrm{~km}^{2}$ (population density $=14.65$ inhabitants/ $\mathrm{km}^{2}$ ) in the Caatinga biome, with a semiarid climate, maximum temperatures range from $33^{\circ} \mathrm{C}$ to $36{ }^{\circ} \mathrm{C}$ and minimum temperatures from $18{ }^{\circ} \mathrm{C}$ to $21^{\circ} \mathrm{C}$. The dry season runs from May to October (precipitation $31 \mathrm{~mm}$ ) and the rainy season runs from November to April (precipitation $625 \mathrm{~mm}$ ). Active search and collection of triatomines by experienced agents was performed in areas both within and peripheral to the studied houses (intradomiciliary and peridomiciliary respectively). The study area included 30 houses in the communities of Grajal $(\mathrm{n}=3)$, Pedra D`Agua $(\mathrm{n}=2)$, Eugênio $(\mathrm{n}=8)$, Marrecas $(\mathrm{n}=1)$, Duque ( $n=1)$, Lagoa ( $n=1)$, Curral Velho ( $n=7)$, Santa Maria

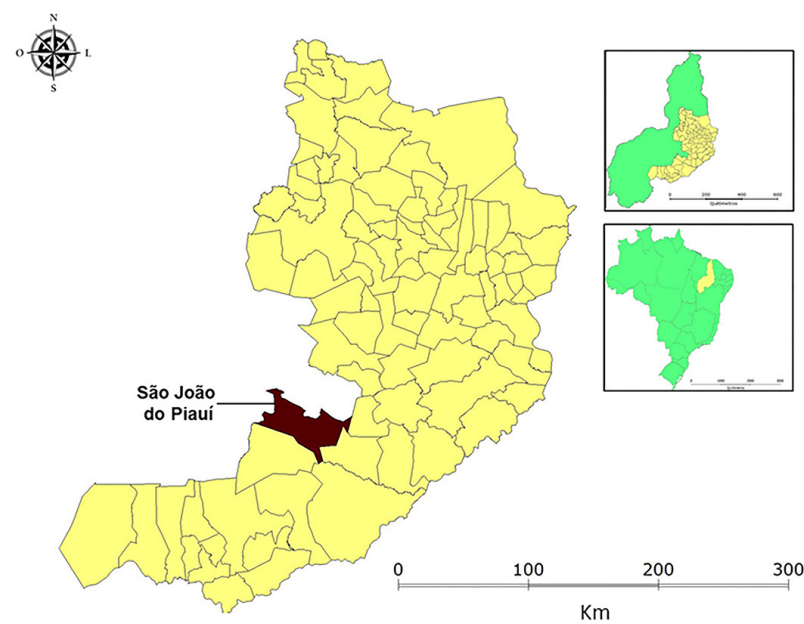

Figure 1 - Map of the state of Piauí, highlighting the municipality of São João do Piauí. $(\mathrm{n}=1)$, Canto do Jepipapo $(\mathrm{n}=4)$, Espinheiro $(\mathrm{n}=1)$, and Lagoa da Serra $(n=1)$. No dislodging substances were used.

\section{RESULTS}

T. cruzi vectors were found in $15(50 \%)$ domiciliary units. A total of 279 specimens were collected; 108 (38.8\%) of these were intradomiciliary colonies (Figure 2A, arrow) characterized by the presence of all developmental instars of insects, including eggs (Figure 2B, arrow). Among intradomiciliary insects, 73 (67.6\%) were nymphal instars: $\mathrm{N} 1=6, \mathrm{~N} 2=14, \mathrm{~N} 3=28, \mathrm{~N} 4=7$ and N5=18. Specimens were found in abundance beneath bed mattresses, and inside cracked mud walls (Figure 2A) as well as on the surface of plastered walls.

Highly engorged insects were recovered from inside the houses (Figure 2C). Sixty-one adult insects (40 females and 21 males) were identified by taxonomic keys proposed by Costa $\mathrm{et} \mathrm{al}$. in 2014. Since all adults corresponded to T. b. macromelasoma (Figure 3), it was inferred that all immature specimens belonged to this species. Triatomines were also present in the peridomiciliary areas of houses, mainly in chicken huts and piles of tiles. The mean number of insects caught per household was 19.9 (range $=1-99$; standard deviation $(\mathrm{SD})=26.2$ ). The mean number of insects inside positive houses was 9.5 (range $=1-37$; $\mathrm{SD}=11.2$ ). Among the studied houses, three were mud huts (pau-a-pique) and 27 were of brick construction. Table 1 summarizes the distribution of Chagas disease vectors by stage and community.

\section{DISCUSSION}

The present study demonstrates the presence of Chagas disease vectors in large densities within homes of several rural communities of São João do Piauí, Northeast Brazil.

The Southwest region of the State of Piaui where the studied communities are located has been recognized in the past as an endemic area to Chagas disease ${ }^{12,13}$. A seroepidemiological survey carried out in 2002 revealed that the prevalence rate of $T$. cruzi infection reached $11.6 \%$ in São João do Piauí, the highest in the State ${ }^{12}$. It is an area belonging to the caatinga biome, an environment favorable to the survival of members of the T. brasiliensis complex, as evidenced by its high relative densities in the region ${ }^{14}$. In Southwestern Piauí, the enzootic transmission cycle of $T$. cruzi has been demonstrated in wild mammals and domestic animals, such as $\operatorname{dog} \mathrm{s}^{15,16}$. In the caatinga region, T. brasiliensis can be found in rock crevices, feeding on small mammals, their main source of food, and with which they share shelter from high local temperatures ${ }^{7-17}$. 

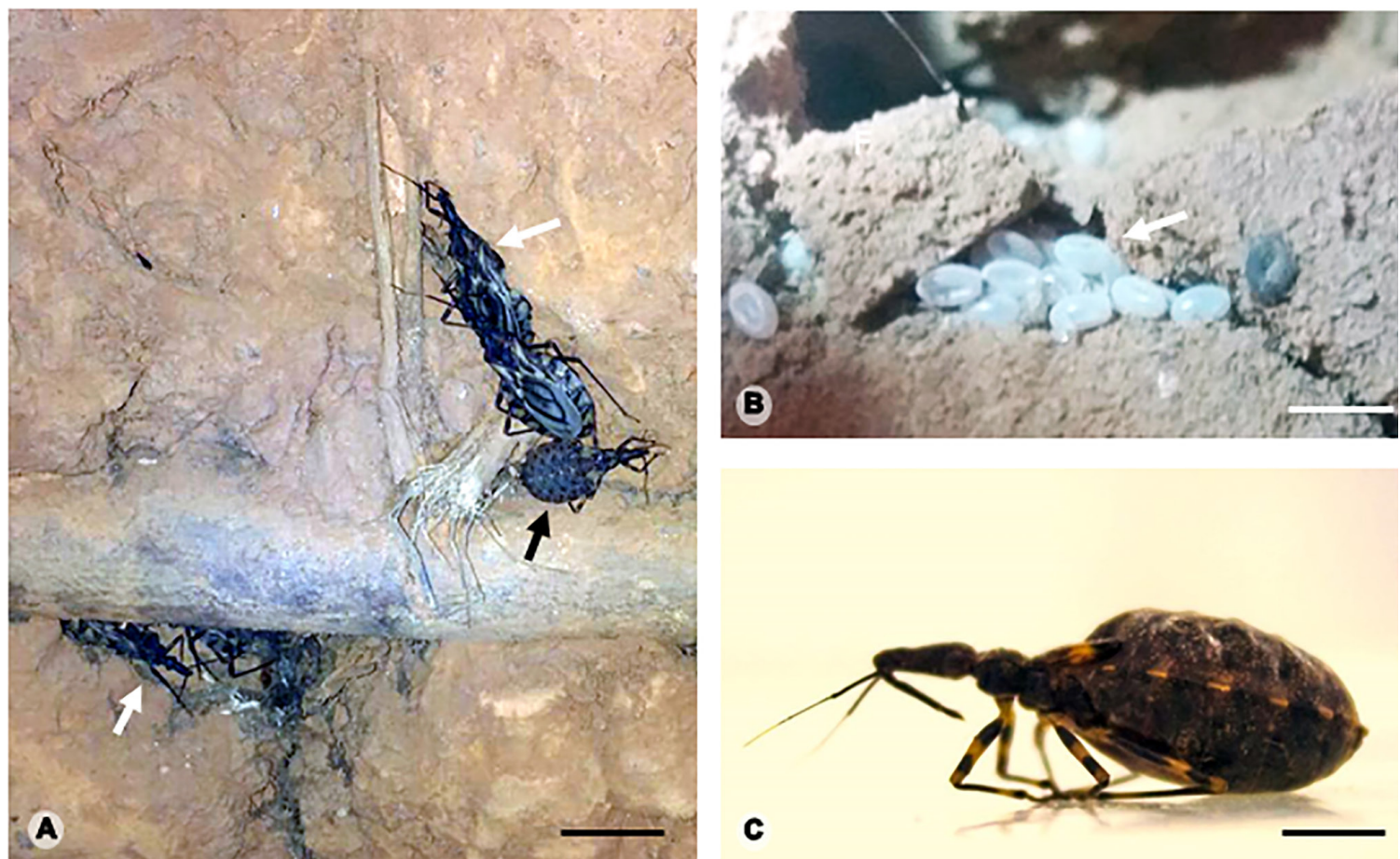

Figure 2 - A, arrow. Triatomine nymphs and adults found colonising a house; B, arrow. Ocluded eggs of triatomines found in house interior; C. Highly engorged nymph found in the domestic environment.

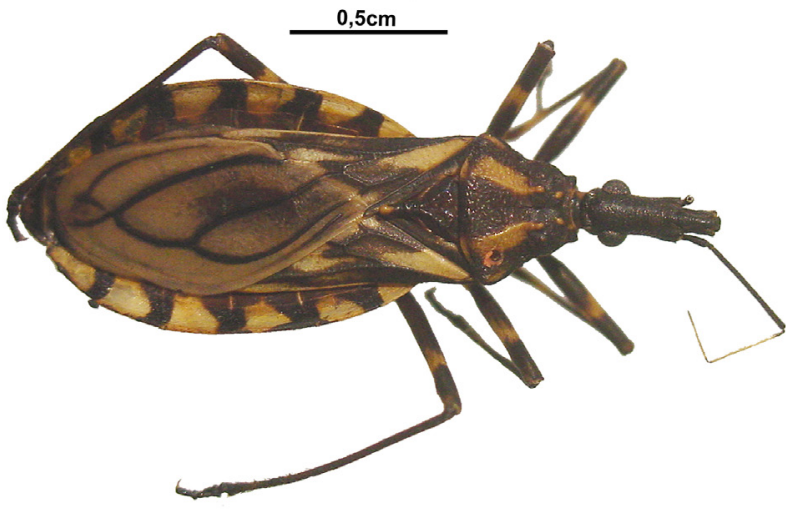

Figure 3 - Triatoma brasiliensis macromelasoma adult collected in São João do Piauí.
It is important to emphasize that Chagas disease control strategies, comprised of entomological surveillance and domestic insecticide spraying, have been discontinued in the study area. Indeed, the workforce of technicians and agents that implemented these practices has been diverted to projects of higher priority status, such as the control of the mosquito Aedes aegypti (Linnaeus, 1762).

The cessation of Chagas disease control activities in a region where the wild environment is favorable to the survival of important vectors such as $T$. brasiliensis, often leads to recolonization of peridomestic environments; mainly chicken coops and corrals ${ }^{18}$. In this case, vectors of Chagas disease are attracted from the forest by food sources

Table 1 - Distribution of triatomines by community and instar in rural areas of São João do Piauí, State of Piauí, Brazil.

\begin{tabular}{|c|c|c|c|c|c|c|c|c|}
\hline \multirow{2}{*}{ Community } & \multicolumn{8}{|c|}{ Instar } \\
\hline & Female & Male & $\mathrm{N} 1{ }^{*}$ & N2 & N3 & N4 & N5 & Total \\
\hline Canto do Jenipapo & 12 & 3 & 2 & 13 & 29 & 18 & 50 & 127 \\
\hline Curral Velho & 4 & 3 & 0 & 1 & 6 & 1 & 5 & 20 \\
\hline Duque & 6 & 4 & 3 & 6 & 13 & 2 & 11 & 45 \\
\hline Espinheiro & 0 & 0 & 2 & 1 & 4 & 3 & 2 & 12 \\
\hline Eugenio & 6 & 5 & 3 & 10 & 12 & 2 & 4 & 42 \\
\hline Lagoa & 7 & 1 & 0 & 0 & 1 & 0 & 4 & 13 \\
\hline Lagoa da Serra & 2 & 0 & 0 & 0 & 1 & 0 & 2 & 5 \\
\hline Pedra D'água & 1 & 2 & 0 & 0 & 1 & 0 & 1 & 5 \\
\hline Santa Maria & 2 & 3 & 0 & 0 & 0 & 0 & 5 & 10 \\
\hline Total & $40^{* *}$ & $21^{* *}$ & 10 & 31 & 67 & 26 & 84 & 279 \\
\hline
\end{tabular}


represented by chickens, dogs and cats among others. This is exacerbated during the dry season when there are few wild animals available to serve as food sources in the forest.

Interestingly domestic colonization in the study area seems to occur independently of the existence of a link between the wild environment and the houses. Large intradomiciliary colonies were observed where human inhabitants were clearly serving as food sources for triatomines. Immature insect stages were frequently captured under bed mattresses and inside cracks in the walls of mud houses. This ecoepidemiological picture illustrates the risk of vector-borne transmission of Chagas disease in Southwestern Piauí.

According to occurrence data synthetized by Costa et $a l .{ }^{19}$, components of the T. brasiliensis complex have a relatively well defined geographic distribution; T. $b$. brasiliensis being more frequent in the States of Paraíba, Rio Grande do Norte, Ceará and Piauí; T. b. macromelasoma in Pernambuco; T. juazeirensis in Bahia; T. melanica in Minas Gerais; T. sherlocki seems to be restricted to Western Bahia. The studied area is situated in Southeastern Piauí, approximately $100 \mathrm{~km}$ from the border of Pernambuco State. Insects collected in this study were classified as T. b. macromelasoma. This is the second report of this subspecies in the State of Piaui ${ }^{20}$.

In the State of Piauí, a comparison of the epidemiological situation before and after the control measures of PCDCh shows a positive impact, with a significant reduction in the seroprevalence rates between the 1970 s and the early 21 st century ${ }^{14}$. Nonetheless, two aspects should be emphasized: i) for 14 years no prevalence studies have been carried out so that the current knowledge regarding the transmission rate is lacking and ii) PCDCh has been discontinued in the majority of the State's municipalities.

Data from this study reaffirm the need for the reimplementation of Chagas disease control activities in the State of Piaui as well as prevalence surveys in order to characterize the current Chagas disease morbidity pattern in the State.

\section{REFERENCES}

1. Justi SA, Galvão C. The evolutionary origin of diversity in Chagas Disease vectors. Trends Parasitol. 2017;33:42-52.

2. Brenière SF, Waleckx E, Barnabé C. Over six thousand Trypanosoma cruzi strains classified into Discrete Typing Units (DTUs): attempt at an inventory. PLoS Negl Trop Dis. 2016;10:e0004792.

3. Rassi A, Luquetti AO, Ornelas JF, Ervilha JF, Rassi GG, Rassi Júnior A, et al. Impacto do controle químico extensivo de Triatoma infestans sobre a incidência de casos agudos e a prevalência de doença de Chagas: o exemplo de Montalvânia, Minas Gerais. Rev Soc Bras Med Trop. 2003;36:719-27.

4. Schofield CJ, Dias JC. The Southern Cone Initiative against Chagas disease. Adv Parasitol. 1999;42:1-27.

5. Costa J, Almeida CE, Dotson EM, Lins A, Vinhaes M, Silveira AC, Beard CB. The epidemiological importance of Triatoma brasiliensis as a Chagas disease vector in Brazil: a revision of domiciliary captures during 1993-1999. Mem Inst Oswaldo Cruz. 2003;98:443-9.

6. Costa J, Peterson AT, Beard CB. Ecological niche modeling and differentiation of populations of Triatoma brasiliensis Neiva, 1911, the most important Chagas disease vector in northeastern Brazil (Hemiptera, Reduviidae, Triatominae). Am J Trop Med Hyg. 2002;67:516-20.

7. Sarquis O, Carvalho-Costa FA, Toma HK, Georg I, Burgoa MR, Lima MM. Eco-epidemiology of Chagas disease in northeastern Brazil: Triatoma brasiliensis, T. pseudomaculata and Rhodnius nasutus in the sylvatic, peridomestic and domestic environments. Parasitol Res. 2012;110:1481-5.

8. Mendonça VJ, Alevi KC, Pinotti H, Gurgel-Gonçalves R, Pita $\mathrm{S}$, Guerra AL, et al. Revalidation of Triatoma bahiensis Sherlock \& Serafim, 1967 (Hemiptera: Reduviidae) and phylogeny of the T. brasiliensis species complex. Zootaxa. 2016;4107:239-54.

9. Oliveira J, Marcet PL, Takiya DM, Mendonça VJ, Belintani T, Bargues MD, et al. Combined phylogenetic and morphometric information to delimit and unify the Triatoma brasiliensis species complex and the Brasiliensis subcomplex. Acta Trop. 2017;170:140-8.

10. Dias JC, Machado EM, Fernandes AL, Vinhaes MC. Esboço geral e perspectivas da doença de Chagas no Nordeste do Brasil. Cad Saude Publica. 2000;16 Suppl 2:13-34.

11. Diotaiuti L, Faria Filho OF, Carneiro FC, Dias JC, Pires HH, Schofield CJ. Aspectos operacionais do controle do Triatoma brasiliensis. Cad Saude Publica. 2000;16 Suppl 2:61-7.

12. Coura JR, Borges-Pereira J, Alves Filho FI, de Castro JA, da Cunha RV, Costa W, et al. Morbidade da doença de Chagas em áreas do Sertão da Paraíba e da Caatinga do Piauí. Rev Soc Bras Med Trop. 1996;29:197-205.

13. Borges-Pereira J, Xavier SS, de Sousa AS, de Castro JA, Zauza PL, Coura JR. Prevalência de aneurismas do ventrículo esquerdo em pacientes chagásicos crônicos de duas áreas do Estado do Piauí. Rev Soc Bras Med Trop. 2007;40:521-6.

14. Borges-Pereira J, Castro JA, Silva AG, Zauza PL, Bulhões TP, Gonçalves ME, et al. Soroprevalência da infecção chagásica no Estado do Piauí, 2002. Rev Soc Bras Med Trop. 2006;39:530-9.

15. Xavier SC, Vaz VC, D'Andrea PS, Herrera L, Emperaire L, Alves JR, et al. Mapping of the distribution of Trypanosoma cruzi infection among small wild mammals in a conservation unit and its surroundings (Northeast-Brazil). Parasitol Int. 2007;56:119-28. 
16. Perez TD, Figueiredo FB, Junior AA, Silva VL, Madeira MF, Brazil RP, et al. Prevalence of American trypanosomiasis and leishmaniases in domestic dogs in a rural area of the municipality of São João do Piauí, Piauí state, Brazil. Rev Inst Med Trop São Paulo. 2016;58:79.

17. Sarquis O, Carvalho-Costa FA, Oliveira LS, Duarte R, D'Andrea PS, de Oliveira TG, et al. Ecology of Triatoma brasiliensis in northeastern Brazil: seasonal distribution, feeding resources, and Trypanosoma cruzi infection in a sylvatic population. J Vector Ecol. 2010;35:385-94.

18. Sarquis O, Sposina R, de Oliveira TG, Mac Cord JR, Cabello PH, Borges-Pereira J, et al. Aspects of peridomiciliary ecotopes in rural areas of northeastern Brazil associated to triatomine (Hemiptera, Reduviidae) infestation, vectors of Chagas disease. Mem Inst Oswaldo Cruz. 2006;101:143-7.
19. Costa J, Dornark LL, Almeida CE, Peterson AT. Distributional potential of the Triatoma brasiliensis species complex at present and under scenarios of future climate conditions. Parasit Vectors. 2014;7:238.

20. Mendonça VJ, Campos JH, Monte CA, Pereira FC, Cavalcante RR. Ocorrência de T. brasiliensis macromelasoma e T. juazeirensis (Hemiptera:Reduviidae) no Estado do Piauí. In: $52^{\circ}$ Congresso da Sociedade Brasileira de Medicina Tropical; 2016 Aug 21-24; Maceió, Espírito Santo, Brazil. [cited 2017 Jan 20]. Available from: http://www.sbmt.org.br/medtrop2016/ wp-content/uploads/2016/10/9024-Ocorre\%CC\%82ncia-deT.-brasiliensis-macromelasoma-e-T.-juazeirensis-HemipteraReduviidae-no-Estado-do-Piaui\%CC\%81.pdf 